\title{
PROTEIN PROFILE AND MDA SPERMATOZOA LEVELS OF HYPERGLYCEMIC MICE FED BY BEAN SPROUTS EXTRACT
}

\author{
Erwin Hidayat*, R. Susanti, Aditya Marianti
}

Department of Biology Faculty of Mathematic and Science.

State University of Semarang

Jalan Semarang No 5 65145

Submitted: $13-04-2015$

Revised: $17-05-2015$

Accepted: 21-06-2015

*Corresponding author Erwin Hidayat

Email: erwinhidayat819@yahoo. co.id

\begin{abstract}
Hyperglycemic conditions resulted in an increase in lipid peroxide would damage the structure and fluidity of membrane, causing the disturbance in membrane functions. Degradation of the membrane cause damage to important cellular components such as DNA and proteins. On the other hand, MDA (malondialdehyde) levels in diabetes mellitus patients increased compared that of control. Phytosterol and vitamin $E$ in bean sprouts is an antioxidant that is able to maintain the integrity of cell membrane. The aim of this study is to analyze the protein profiles and MDA levels in spermatozoa of hyperglycemic mice given bean sprouts extract. This study is an experimental study with post test-only control group design. The methods of this study including the preparation of 28 mice that was divided into 4 groups: control, P1, P2, and P3 groups. The test groups (P1, P2, and P3) were induced with monohydrate alloxan at a dose of $150 \mathrm{mg} / \mathrm{kg}$ for 5 days. $\mathrm{P} 2$ group were given bean sprouts extract at a dose of $50 \mathrm{mg} / 20 \mathrm{~g}$ and $\mathrm{P} 3$ group were given bean sprouts extract at a dose of $100 \mathrm{mg} / 20 \mathrm{~g}$. Spermatozoa were collected on day 36 for MDA levels determination using TBARS and protein profiles analyzing using SDS-PAGE. The obtained data of MDA levels were analyzed using one-way ANOVA continued with LSD test, whereas the protein profiles data were qualitative descriptively analyzed. From the overall data of this study, the MDA levels showed significant differences among each groups: control P1, P2 and P3 groups were $2.43 \mathrm{nmol} / \mathrm{mL}, 7.89 \mathrm{nmol} / \mathrm{mL}$, $5.19 \mathrm{nmol} / \mathrm{mL}$, and $3.29 \mathrm{nmol} / \mathrm{mL}$, respetively. Protein profiles analysis results showed that there was 8 protein bands in control group and P3 group; $72,60,49,42,35,30,28$, and $23 \mathrm{kDa}$; whereas that were not found any protein band in P1 and P2 groups. Bean sprouts extract contains a-tocopherol as antioxidant. Tocopherol works as free radical oxygen, lipid peroxide, and singlet oxygen. It was summarized that bean sprouts extract at a dose of $100 \mathrm{mg} / 20 \mathrm{~g}$ had influenced on recovery of protein profiles and the decrease of MDA levels in spermatozoa of hiperglycemic mice induced alloxan.
\end{abstract}

Keywords: Protein profiles, MDA, Hyperglicemic, Bean Sprouts

\section{INTRODUCTION}

Diabetes mellitus is a chronic hyperglycemic condition caused by insulin secretion disorder, the action of the insulin itself, or caused by both together with various metabolic disorders caused by hormonal disturbance; resulted in various chronic complications on eyes, kidney, nerves, and blood vessel, accompanied with lessions in basalis membrane under electron microscope observation (Mansjoer et al., 2000). Metabolic disorders in DM can be linked with a lot of organ systems pathophysiology and can caused microvascular and macrovascular complications. The exponential increase of DM incidences are certain to be followed by the probability increase of chronic DM complications. One of the complication is on male reproduction system. DM has long been known to decrease male fertility and interfere with spermatogenesis and erectile function. The study states that men with DM have significantly higher in sperm DNA fragmentation due to increased oxidative stress 
(Agbaje et al., 2007). DM is a systemic disease that causes infertility (Bashandy, 2007).

Oxidative stress occurs when there is an increase in free radicals formation and slowdown in neutralization and disposal system of free radicals. There is an interplay between advanced glycation products and reactive oxygen species (ROS). MDA measurement often be used as a parameter in lipid peroxide formation. High lipid peroxide appears to have links with various diseases. That statement was proved in some studies, one of them was Suryawanshi et al. (2006) reported that in patients with DM the MDA levels increased compared to control. In addition to Zarghami and Khosrowbetgi (2005) research, it showed that men who have asthenozoospermic have an increased MDA levels in semen compared with men with monozoospermic, and it was correlated with the reduction of spermatozoa motility.

Bean sprouts is known empirically as an icon or logo for man fertility. Bean sprouts contains a lot of tocopherol and vitamin E, even though phenol and some minerals (selenium, manganese, copper, zinc, and iron) also have a significant amount (Astawan, 2005; Shetty et al., 2000; Winarsi, 2007). Green bean sprouts (Vigna radiata) is a kind of bean from Leguminosae family, include as dicotyledone plants (having a pair fragment of seeds) which is rich in nutritions as food storage for embryo during germination. Green beans during germination are rich in active enzymes such as amylase that raised the absorption and energy formation. Bean sprouts also contains phytosterol $(15 \mathrm{mg} / 100 \mathrm{mg})$ as antioxidant (Maulana, 2010).

\section{MATERIAL AND METHODS}

This study is an experimental study with post test-only control group design. In this study, mice were divided into control group, test group (P1, P2, and P3) that were injected with alloxan at a dose of $150 \mathrm{mg} / \mathrm{kg}$. Mice were given pellet as food and drink that contains $10 \%$ glucose for 2 days after given alloxan. On day 3 and after, the drink that contains 10\% glucose was replaced with normal water; and after 5 days, measurement on blood glucose levels were conducted using Glucose Analyzet Kit for comparing blood glucose levels between test groups (given alloxan) and control group. On day 6, P2 group were given bean sprouts extract at a dose of $50 \mathrm{mg} / 20 \mathrm{~g}$ and P3 group were given bean sprouts extract at a dose of $100 \mathrm{mg} / 20 \mathrm{~g}$ for 30 days. On day 36, the necropsy was performed on samples for test variable collecting.

\section{Preparation of bean sprouts extract}

Bean sprouts extract in this study was obtained according to Zigoneanu (2006) method. Before bean sprouts were mixed with solvent (hexane), first bean sprouts were mashed using blender so that it easier to mixed with solvent. The mashed bean sprouts were mixed with hexane with the ratio of hexane and bean sprouts 3:1 v/w, poured into Erlenmeyer flask, and then shaked to homogenized it. After that, the mixture was put in $50^{\circ} \mathrm{C}$ water bath for $15 \mathrm{~min}$ while keep shaken. Bean sprouts extract was cooled for $20 \mathrm{~min}$, then filtered using filter paper. The last step was evaporation of the obtained filtrate using evaporator, to evaporating the solvent so that the bean sprouts extract could be obtained in paste form.

\section{Sperm collecting}

Sperm collecting from mice testes was performed according to the method of Suparni (2009). After 35 days of treatment, each animal were necropsied by means cervical dislocation and then dissected. The right testes organs were taken and placed in petri dish containing $0.9 \%$ $\mathrm{NaCl}$. The testes was dissected under microscope with a magnification of 400X. Cauda epididymis was separated by cutting the proximal corpus epididymis part and distal vas deferens part. Cauda epididymis was placed on watch glass containing $1 \mathrm{~mL}$ of $0.9 \% \mathrm{NaCl}$. Proximal cauda was cut with scissor and then pressed gently until the epididymal fluid secreted out and suspended with $0.9 \% \mathrm{NaCl}$. The obtained sperm suspension could be used for protein analysis.

\section{Spermatozoa protein isolation}

Mice spermatozoa samples were placed in eppendorf tubes and added with PBS (1:1), vortexed and then centifuged at $3000 \mathrm{rpm}$ (room temperature, $10 \mathrm{~min}$ ); this process was performed twice. The product was a pellet, 
added with Tween-20 detergent containing $4 \mathrm{mM}$ PMSF (9:1), vortexed for 10min, sonicated using an ultrasonic cleaner for $20 \mathrm{~min}$, and centrifuged again at $12.000 \mathrm{rpm}\left(40^{\circ} \mathrm{C}\right.$, $10 \mathrm{~min})$. The obtained supernatant was added ethanol at 1:1 ratio and put in the refrigerator for $60 \mathrm{~min}$ (if it was not formed white clumps yet, the time was prolonged). If the white clumps (spermatozoa protein) were already formed, it was then centrifuged at $10.000 \mathrm{rpm}$ $\left(40^{\circ} \mathrm{C}, 10 \mathrm{~min}\right)$ until the clumps were precipitated and then put in the refrigerator at $20^{\circ} \mathrm{C}$ for $5 \mathrm{~min}$. Ethanol in the extract was removed and aired until the odor of ethanol vanished. The spermatozoa membrane protein isolate was dilluted with Tris- $\mathrm{Cl}$ buffer at ratio of 1:1 with the precipitate volume of crude spermatozoa protein isolate (Tenzer and Lestari, 2009).

\section{Molecular weight determination Gel Preparation}

The gel plate was made by assembling two glass plates with $\pm 1 \mathrm{~mm}$ length between plates. The gel was made into two layers, gel for placing the sample (stacking gel) and gel as a medium for protein separation (separating gel). Separating gel was made by mixing all materials except for ammonium persulfate (APS) and $\mathrm{N}, \mathrm{N}, \mathrm{N}^{\prime}, \mathrm{N}^{\prime}$ tetramethylethylenediamine (TEMED), and then it was deggased for 10 minutes. APS and TEMED were added, shaken briefly, then put in the plate and let it stayed for 10-30min until the gel hardened. Stacking gel was made in the same way as separating gel without degassing, and after the separating gel got hardened, the stacking gel solution was poured over it and the comb was set on it until the gel hardened and formed the pitting (wells). The plate was mounted on mini tool set of gel protein electrophoresis and the running buffer was poured on the device (Muchtaromah, 2012). The concentration of separating gel used was $12.5 \%$ and stacking gel was $5 \%$ with Comasie Brilliant Blue dyed until the protein bands clearly visible (Susan and Rahayu, 2012).

\section{Sample Injection}

Samples containing $12.5 \mu \mathrm{L}$ of protein isolate and $12.5 \mu \mathrm{L}$ of reducing sample buffer (RSB) were heated in a water bath at $100^{\circ} \mathrm{C}$ for $2 \mathrm{~min}$. After being cooled the samples were inserted into gel wells with volume of $10 \mathrm{~mL}$ for each well. Protein marker was treated in the same way. The used standard protein was a broad protein marker with the size of 250 $10 \mathrm{kDa}$. After that, anode was connected to the lower reservoir and the cathode was connected to the upper reservoir. Power supply connected with electricity using a current of $30 \mathrm{~mA}$ to 600 volts for $2-3 \mathrm{~h}$. The separation process was stopped when the blue color marker was at $\pm 0.5 \mathrm{~cm}$ length from lower margin of the gel plate (Muchtaromah, 2012).

\section{MDA levels assay}

Malondialdehyde was measured using Thiobarbituric Acid Reactive Substance (TBARS) method, which measures the concentration of TBARS. As much as $750 \mathrm{~mL}$ of phosphoric acid was pippete into $13 \mathrm{~mL}$ Polypropen tube. As much as $500 \mu \mathrm{L}$ of sample was added, then $50 \mu \mathrm{L}$ of TEP standard/quality control/plasma sample/aquadest was added into the tube. The mixture was homogenously shaken, then $250 \mu \mathrm{L}$ of TBA $40 \mathrm{~nm}$ solution was added. As much as $450 \mu \mathrm{L}$ aquadest was added into the tube and then sealed. The mixture was boiled for one hour, and after heating the tube was placed into the ice bath for cooling the sample. The cooled sample was applied into set-pack C18 column. The absorbance was measured with spectrop-hotometer with a wavelength set of 532nm (Hsieh et al., 2006).

\section{Data analysis}

Data from SDS-PAGE electrophoresis of spermatozoa protein profiles were descriptively analyzed by comparing the results of SDS-PAGE protein profiles in control mice, hyperglycemic mice, and hyperglycemic mice given bean sprouts extract. While the MDA levels data were analyzed using one-way ANOVA. If there were significant differences in data, the test continued using (Least Significant Difference) LSD test.

\section{RESULTS AND DISCUSSION \\ Blood sugar levels in mice}

Blood sugar levels in mice were taken before and after treatment. Blood sugar levels data were retrieved using glucose analysis kit. The results of blood sugar levels are presented in table I. 
Erwin Hiday at

Table I. Blood sugar levels mice between group

\begin{tabular}{ccccccccc}
\hline \multirow{2}{*}{ Mice } & \multicolumn{2}{c}{ Control } & \multicolumn{3}{c}{ P1 } & \multicolumn{2}{c}{ P2 } & \multicolumn{2}{c}{ P3 } \\
\cline { 2 - 9 } & \multicolumn{9}{c}{ Blood Sugar Levels } & (mg/dl) & & \\
\cline { 2 - 9 } & Pre & Post & Pre & Post* & Pre & Post* & Pre & Post* $^{*}$ \\
\hline $\mathbf{1}$ & 95 & 110 & 101 & 190 & 81 & 137 & 108 & 131 \\
$\mathbf{2}$ & 99 & 108 & 84 & 128 & 97 & 127 & 119 & 129 \\
$\mathbf{3}$ & 52 & 87 & 108 & 167 & 101 & 126 & 119 & 132 \\
$\mathbf{4}$ & 112 & 99 & 67 & 149 & 84 & 167 & 45 & 133 \\
$\mathbf{5}$ & 71 & 88 & 79 & 148 & 108 & 136 & 142 & 137 \\
$\mathbf{6}$ & 104 & 99 & 87 & 138 & 65 & 138 & 95 & 128 \\
$\mathbf{7}$ & 90 & 101 & 99 & 140 & 69 & 125 & 78 & 152 \\
Average & 89 & 99 & 89 & 151 & 86 & 136 & 101 & 134 \\
\hline
\end{tabular}

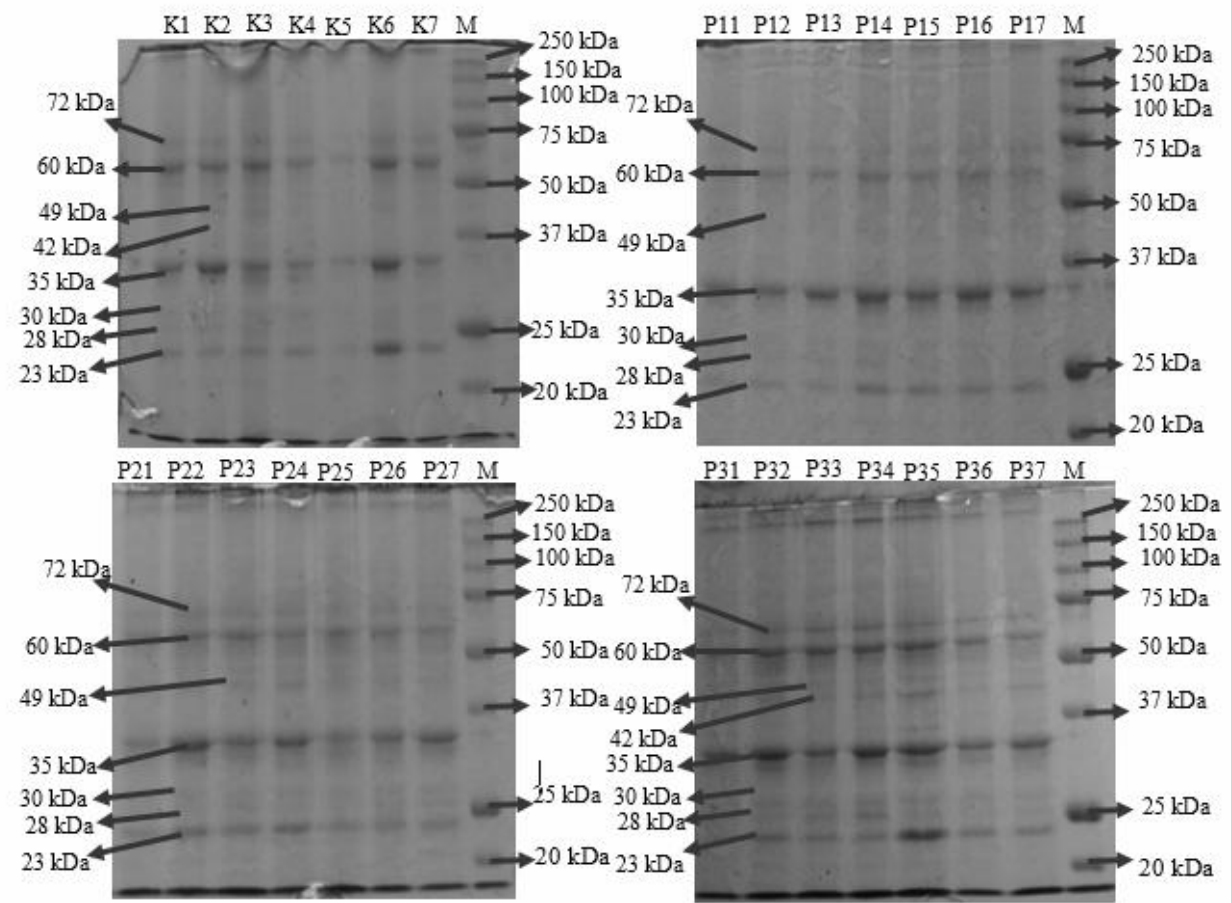

Figure 1. The results protein profile of spermatozoa mice.

The table above shows that there are blood sugar levels differences between groups. P1, P2, and P3 groups showed an increase in blood sugar levels before and after treatment with alloxan at a dose of $150 \mathrm{mg} / \mathrm{kg}$. Blood sugar levels of mice in the treatment groups after induction of alloxan were $\geq 126 \mathrm{mg} / \mathrm{dL}$, so it showed that the mice had undergone experimental diabetic condition (Adam and Fabiola, 2002).

\section{Spermatozoa protein profiles of hyperglycemic mice given bean sprouts extract}

The protein profiles analysis of mice in control group gained 8 protein bands as results, with molecular weight of $72 \mathrm{kDa}, 60 \mathrm{kDa}, 9 \mathrm{kDa}$, $42 \mathrm{kDa}, 35 \mathrm{kDa}, 350 \mathrm{kDa}, 28 \mathrm{kDa}$, and $23 \mathrm{kDa}$. P1 group (induced alloxan at a dose of $150 \mathrm{mg} / \mathrm{kg}$ ) and P2 group (induced alloxan at a dose of $150 \mathrm{mg} / \mathrm{kg}$ and given bean sprouts extract at a dose of $50 \mathrm{mg} / 20 \mathrm{~g}$ ) did not reveal any protein 
bands with molecular weight of $42 \mathrm{kDa}$. While in P3 group (induced alloxan at a dose of $150 \mathrm{mg} / \mathrm{kg}$ and given bean sprouts extract at a dose of $100 \mathrm{mg} / 20 \mathrm{~g}$ ) there were 8 protein bands like in the control group.

The loss of $42 \mathrm{kDa}$ protein in spermatozoa of hyperglycemic mice (diabetic experimental) is caused by many factors. On of them is the presence of elevated levels of ROS during hyperglycemic condition (Awda, 2009). The elevated of ROS levels in hyperglycemic condition is cause by the exhaustion or lack of antioxidant available in spermatozoa, so it is not able to transform the reactive oxygen $(\mathrm{O})$ into a neutral oxygen $\left(\mathrm{O}_{2}\right)$. The poor $\mathrm{O}_{2}$ production induced lipid peroxide transformation (Lamirande et al., 2001). Lipid peroxide damaged the structure and function of membrane by disrupting the phospholipid structure and fluidity of membrane. Increased in extracellular and intracellular of $\mathrm{Ca}^{2+}$ and lipid peroxide in phospholipid membrane will eventually change the structure and degradation of membrane (Awda, 2009). Membrane degradation can lead to degradation of important cellular components such as DNA and proteins. Proteins that have been degraded by ROS will easily move into extracellular medium since the cellular membrane has been broken (Zilli et al., 2005).

Free radicals can also react with nucleotide resulting in change on biological cellular components. If the free radicals damage the thiol group, it will cause changes in enzymes activity. Free radicals can damage the cell by disrupting the cell membrane. Damage to the cell membrane can occur by: (a) free radicals covalently bonded to enzymes or receptors in cell membranes, thus interfere in cell components activity of the membrane; (b) free radicals covalently bonded to components of cell membrane, thus changing the structure and function of the membrane or altering the character of membrane to be like antigen; (c) free radicals interfere in transport system of cell membrane through covalent bonds, oxidize the thiol groups, or changing the poly unsaturated fatty acids; (d) free radicals initiated directly lipid peroxidation of poly unsaturated fatty acids on cell wall. Free radicals will induce lipid peroxidation of cell membrane. This lipid peroxidation will affect the fluidity of membrane, membrane cross-linking, and the structure and function of the membrane itself (Powers and Jackson, 2008).

Research by Honda et al. (2002) showed that proteins with molecular weight of $14 \mathrm{kDa}$ $18 \mathrm{kDa}$ and $41 \mathrm{kDa}-42 \mathrm{kDa}$ were found in the membrane surface of spermatozoa. This proteins act as serine protease on the penetration of pellucida zone (PZ). Nonexpression of serine protease may cause infertility through acrosin blockade, enzyme inside spermatozoa acrosome, which is activated by the penetration. Research by Cheema et al. (2001) showed that proteins with molecular weight of $42 \mathrm{kDa}$ act as secretory proteins. This proteins were found in the membrane surface and they serve to sperm maturation process in epididymis. This suggest that the loss of protein with molecular weight of $42 \mathrm{kDa}$ on mice spermatozoa analysis may results in the possibility of infertility.

Proteins analysis on P3 group that was given bean sprouts extract at a dose of $100 \mathrm{mg} / 20 \mathrm{~g}$ showed a protein band with molecular weight of $42 \mathrm{kDa}$. This is possible because of the antioxidant effects from bean sprouts extract which is rich in tocopherol. Tocopherol is an antioxidant that prevents oxidation and peroxidation of unsaturated fatty acids and membrane phospholipid. Tocopherol also serves to protect biological membrane from damages caused by free radicals. Tocopherol can neutralize hydroxyl, superoxide, and hydrogen peroxide radical groups; and prevents the sperm agglutination (Agarwal et al., 2005). According to Linder (2006), tocopherol is the driving agent of fertility, because it can normalize tubuli semeniferi epithelium. Tocopherol or vitamin $\mathrm{E}$ has the ability to block lipid peroxide by donating a hydrogen atom from $\mathrm{OH}$ group to lipid peroxyl radical, so that it becomes less reactive vitamin $\mathrm{E}$ and does no damage (Hariyatmi, 2004).

\section{Relations between MDA levels and spermatozoa protein profiles}

Further LSD test results of spermatozoa MDA levels showed that spermatozoa MDA levels differ significantly between treatment groups. This indicates that the administration of bean sprouts extract at a dose of $50 \mathrm{mg} / 20 \mathrm{~g}$ 
in P2 group and a dose of $100 \mathrm{mg} / 20 \mathrm{~g}$ in P3 group managed to ward off free radicals caused by hyperglycemic condition, so that the sperm MDA levels can be reduced (Table II).

Hyperglycemic in diabetes mellitus (DM) causes an increased production of free radicals, especially ROS from autoxidation and protein glycosylation in various body tissues. Free radicals are normal byproducts of cellular metabolism. How ever, in some circumstances it may cause balance interference between ROS formation and cellular defense mechanism, causing disfunction and cell damage. Elevated ROS levels in DM can be caused by an increase or decrease in the production of enzymatic or non-enzymatic antioxidants (Retnaningsih et al., 2013).

Table II. Test results of LSD MDA spermatozoa levels of mice given sprouts extract

\begin{tabular}{cc}
\hline Group Average of MDA Levels (nmol/mL) \\
\hline K & $2.3414 \pm 0.284^{\mathrm{a}}$ \\
P1 & $8.2200 \pm 0.295^{\mathrm{b}}$ \\
P2 & $5.0229 \pm 0.198^{\mathrm{c}}$ \\
P3 & $3.1857 \pm 0.183^{\mathrm{d}}$ \\
\hline
\end{tabular}

Description: Different letters indicate significant differences.

The latest research states that hyperglycemia stimulates the release of superoxide $\left(\mathrm{O}^{2-}\right)$ at mitochondria level as an initial trigger of oxidative stress in patients with DM, by activating nuclear factor kappa B cells (NF-kB), mitogen-activated protein kinase (MAPK) p38, polyol (sorbitol) pathway, hexoaminase, protein kinase $\mathrm{C}$ (PKC), and advanced glycosylation product (AGEs). Elevated levels of PKC and AGEs lead to a positive feedback of ROS and reactive nitrogen species (RNS) synthesis, giving rise to vascular abnormality in patients with DM (Santoso and Waspadji, 2008). Stress oxidative in patients with DM may occur through enzymatic, nonenzymatic, and mitochondrial pathways (Wibowo, 2013).

The results of this study showed an increase of free radicals in P1 group which the mice been made experimentally diabetic by alloxan induction, compared with control group. The elevated free radicals levels were characterized by high MDA levels in spermatozoa of hyperglycemic mice amounted to $8.22 \mathrm{nmol} / \mathrm{mL}$, whereas the MDA levels of control group amounted to $2.34 \mathrm{nmol} / \mathrm{mL}$. The high levels of ROS in body can lead to higher MDA levels, that is dialdehyde compound as end product of lipid peroxidation in the body. MDA is also one of cell metabolite component produced by free radicals. Therefore, high levels MDA indicate the presence of oxidation processes in the cell membrane. MDA can react with nucleophilic or electrophillic components. MDA can bind covalently to various biological molecules such as proteins, nucleic acids, phospholipid amino (Winarsi, 2007). Malondialdehyde formed by lipid peroxidation in cell membrane, that is a reaction between free radicals and Poly Unsaturated Fatty Acid (PUFA). MDA is toxic to cells and can cause DNA changes even to the degree of mutagenic lession oxidation (Winarsi, 2011).

High levels of ROS in spermatozoa of hyperglycemic mice can be reduced by administration of bean sprouts extract. The results of MDA levels measurement in spermatozoa of hyperglycemic mice in P2 and P3 groups showed decreased levels of MDA. In P2 group, after treatment with bean sprouts extract at a dose of $50 \mathrm{mg} / 20 \mathrm{~g}$, the spermatozoa MDA levels of hyperglycemic mice was amounted to $5.02 \mathrm{nmol} / \mathrm{mL}$. In P3 group, after treatment with bean sprouts extract at a dose of $100 \mathrm{mg} / 20 \mathrm{~g}$, the spermatozoa MDA levels of hyperglycemic mice was amounted to 3.18 $\mathrm{nmol} / \mathrm{mL}$. Based on the results of statistical analysis, it showed that both doses of bean sprouts extract were able to significantly reduced spermatozoa MDA levels of hyperglycemic mice. Although treatment with bean sprouts extract at a dose of $50 \mathrm{mg} / 20 \mathrm{~g}$ already reduced the MDA levels, but it had not yet matched the spermatozoa MDA levels of hyperglycemic mice at normal condition. Levels of spermatozoa MDA in mice were said to be normal when the MDA levels $\leq 4 \mathrm{nmol} / \mathrm{mL}$ (Hsieh et al., 2006).

The decreased levels of MDA in spermatozoa of hyperglycemic mice were caused by bean sprouts extract that contained $\alpha$-tocopherol or vitamin E. $\alpha$-tocopherol is one of secondary antioxidant, i.e compounds that 
capture free radicals and prevent the occurrence of chain reactions. $\alpha$-tocopherol is the most abundant antioxidant in bean sprouts than other antioxidants. Vitamin E can inhibit lipid peroxidation by free radicals formed by NAPQI reaction through free radicals scavenger and metal chelation mechanisms (Priya and Vasudha, 2009). Vitamin E protects unsaturated fatty acids from oxidation and maintains the intracellular balance (Yulfiperius et al., 2003). This compound also being reported as scavenger of oxygen free radicals, lipid peroxide, and singlet oxygen (Winarsi, 2007). As an antioxidant, vitamin $\mathrm{E}$ serves as a hydrogen ion donor capable of altering peroxyl radicals into tocopherol radicals that less reactive, so it is not capable to do any damage on fatty acid chains (Wardlaw and Jeffrey, 2007).

\section{CONCLUSION}

Bean sprouts extract at a dose of 100 $\mathrm{mg} / 20 \mathrm{~g}$ affected the recovery of protein profiles and the decreased levels of MDA in spermatozoa of hyperglycemic mice induced alloxan.

\section{ACKNOWLEDGEMENT}

Authors are grateful to Dinas Pendidikan Propinsi Jawa Tengah for the Research Grants that have been given.

\section{REFERENCE}

Adam, Fabiola MS., 2002. Diagnosis and Classification of Diabetes Mellitus. Bogor: PT Dexa Medica.

Agarwal A., Prabakaran SA., 2005. Oxidative Stress and Antioxidants in Male Infertility: a Difficult Balance. Iranian Journal of Reproduction Medice 3 (1): 1-8.

Agbaje IM., Rogers DA., McVicar CM., McClure N., Atkinson AB., Mallidis C., Lewis SE. 2007. Insulin Dependant Diabetes Mellitus: Implications For Male Reproductive Function. Human Reprododuction 22 (7):1871-1877.

Awda BJ., Mackenzie-Bell M., Buhr MM. 2009. Reactive Oxygen Species and Boar Sperm Function. Biology of Reproduction (81): 553-561.
Bashandy AES., 2007. Effect Of Fixed Oil Nigella Sativa On Male Fertility In Normal And Hyperlipidemic Rats. Int. J Parmacology 3 (1): 27-33.

David G., S Dolores., 2007. Greenspan's Basic and Clinical Endocrinology $8^{\text {th }}$ Edition. Lange McGraw-Hill; Available from: pf MED:CINE.

Fauzi TM., 2008. Effect of Lead Acetate and Vitamin C Against Lipid peroxidation And Quality In Secretion epididymis spermatozoa male mice (Mus musculus L.) Strains DDW .Tesis. Medan:Universitas Sumatera Utara.

Hariyatmi., 2004. The Ability of Vitamin E as an Antioxidant Against Free Fadicals in the Elderly. Jurnal MIP A UMS 14: 52-60

Honda A., Yagamata K., Sugiura S., Watanabe K., Baba T., 2002. A Mouse Serine Protease TESP5 Is Selectively Included into Lipid Rafts of Sperm Membrane Presumably as a Glycosylphosphatidylinositol-anchores Protein. J. Biol. Chem 277: 16976-16984.

Hsieh YY., Chang CC., CS Lin., 2006. Seminal Malondialdehyde Concentration But Not Glutation Peroxide Activity is Negatively Correlated With Seminal Concentration and Motility. Int J Bol.Sci 2 (1): 23-29.

Iswara A., 2009. Effect of Vitamin C and E on the Quality of Spermatozoa Rats Exposed Allterin. Skripsi. Biologi Unnes.

Lamirande ED., Yoshida K., Yoshiike M., Iwamato T., Gagnon C., 2001. Impact Of Reactive Oxygen Species On Spermatozoa: A Balancing Act Between Beneficial And Detrimental Effects. J. Andrology 22 (4): 672-679.

Linder MC., 2006. Nutritional Biochemistry and Metabolism. Diterjemahkan oleh A. Prakkasi. Jakarta: UI Press

Mansjoer A., 2000. Capita Selecta Medicine, Third Edition. Universitas Indonesia. Jakarta

Maulana AI. 2010. Effect of Extract Sprouts (Phaseolus radiatus) Renal Cell Damage mice (Mus musculus) Paracetamol Induced(Skripsi). Universitas Sebelas Maret. Surkarta 
Powers SK., Jackson MJ. 2008. ExerciseInduced Oxidative Stress: Cellular Mechanisms and Impact on Muscle Force Production. Physiol 88 (4): 12431276.

Priya R., Vasudha K. 2009. Antioxidant Vitamins in Chronic Renal Failure. Biomed Research 20 (1): 67-70.

Retnaningsih C,. Darmono., Widianarko B., \& Muis SF., 2013. Increased superoxide dismutase Antioxidant Activity In Mice Hyperglycemia Intake Surly With Tempe Koro (Mucuna pruriens L). Agritech 33 (2): 154-161.

Santoso O., Waspadji S., 2008. The Effect of Non-surgical Periodontal Therapy on Systemic Immune response and Blood Glucose Level of NIDDM Patients. Med $J$ Indones 17(1): 20-24.

Schroter S., Osterhoff C., McArdle W \& Ivell R., 1999. The Glycocalyx of The Sperm Surface. Hum Reprod Update 5 (4): 302312

Suryawanshi NP., Bhutey AK., Nagdeote AN., Jadhav AA \& Manoorkar GS., 2006. Study of Lipid Peroxide and Lipid Profile in Diabetes Melitus. Indian Journal ClinicalBiochemistry 21 (1): 126-130.

Susan MD., Rahayu S. 2012, Protein profiles spermatozoa After Freezing (Artikel Ilmiah). Malang: Universitas Brawijaya
Taufiqqurohman MA., 2008, Introduction to Research Methodology for Health Sciences, Solo: Universitas Negeri Sebelas Maret.

Tenzer A., Lestari U. 2009. Glycoprotein of Human Spermatozoa. Malang: Veterinaria Medika 2 (1): 29-34

Wibowo JW., 2013., Effect of Supplementation of Flour Tempe Over Glutathione peroxidase levels Against Bunting (GPx) and malondialdehyde (MDA) Child Rat., Sains Medika 5(1): 38-44.

Winarsi H., 2007. Natural Antioxidants and Free Radicals, Kanisius, Yogyakarta.

Wardlaw GM., Jeffrey SH., 2007. Perspectives in Nutrition: The Vitamins and Minerals. $7^{\text {th }}$ ed, Mc Graw Hill, New York

Yulfiperius., Mokoginta I., Jusadi D., 2003. Effect of Vitamin E Levels in Animal Feed on the Quality of Eggs catfish (Pangasius hypophthalmus). Jurnal Iktiologi Indonesia 3 (1): 11-18.

Zigoneanu IG., 2006, Alpha-Tocopherol: Extraction From Rice Bran by Microwave-Assisted Method, and Entrapment and Release From Polymeric Nanoparticles, Thesis, Lousiana State University, Romania

Zilli L., Sciavone R., Zonno V., Rossano R., Storelli C., Vilella S., 2005. Effect of Cryopreservation on Sea Bass Sperm Proteins. Biology of Reproduction 1 (72): 1262-1267 